\title{
Changing Pattern of Input Cost in Tamil Nadu, India
}

\author{
V. Kavitha* and M. Chinnadurai \\ Centre for Agricultural and Rural development Studies, Tamil Nadu Agricultural University, \\ Coimbatore - 641003, Tamil Nadu, India \\ *Corresponding author
}

\begin{tabular}{|l|l|}
\hline \multicolumn{1}{l}{ A B S T R A C T } \\
\cline { 2 - 2 } \multicolumn{1}{l|}{\begin{tabular}{l}
\hline Keywords \\
$\begin{array}{l}\text { Agrarian crisis, } \\
\text { efficiency. }\end{array}$
\end{tabular}} & $\begin{array}{l}\text { An attempt has been made in this paper to estimate and compare how the } \\
\text { cost of cultivation of crops changes over the period. The analysis is based } \\
\text { on the cost of cultivation data collected from reports of Commission for } \\
\text { Agricultural Costs and Prices, Directorate of Economics and Statistics, } \\
\text { Government of India for the two major crops of Tamil Nadu, paddy and } \\
\text { sugarcane for the period 2000-01 to 2014-15. The results of the study } \\
\text { showed that rise in cost of cultivation were tremendously higher than the } \\
\text { rise in profit. The study suggested for scheduled application of fertilisers } \\
\text { and maximum possible mechanization of crop cultivation in order to reduce } \\
\text { the cost of production. }\end{array}$ \\
\hline $\begin{array}{l}\text { Accepted: } \\
\text { Available Online: } \\
\text { 10 December 2017 }\end{array}$
\end{tabular}

\section{Introduction}

As the country is marching towards economic development, India has seen a decline in the number of people who depends on agriculture for livelihood. In the year between 2001 and 2011, the number of Indian farmers declined by 9 million people. Climate change is identified as one among the major factor contributing for the decline in agrarian population. Farmers in India, rely heavily on the monsoon each year for their crops. Nowadays, weather in India has become erratic. India's Intergovernmental Panel on Climate Change (IPCC) has predicted that "rainfall patterns particularly in peninsular India will become more erratic, with a possible decrease in total rainfall and an increase in extreme weather events."
If drought occurs farmers are left without harvest, despite having spent enormous amounts of money on inputs like fertilizer and seeds. Often, years with the most devastating weather results in more farmer suicides.

Insufficient rainfall and thereby poor harvest and mounting cost of cultivation were cited as major reasons for farmer suicides. Hence this study aims at studying the changes in cost of cultivation over the years for the two major crops of Tamil Nadu, Paddy and Sugarcane.

\section{Materials and Methods}

Among the different Agricultural Economic Policies of the Government of India, the 
Agricultural Price Policy has been playing a significant role in bringing about major changes in the production of the agricultural sector. Under its price policy, the Union Government announces Minimum Support Prices (MSPs) of important agricultural commodities, on the recommendations of Commission for Agricultural Costs and Prices (CACP) under the Directorate of Economics \& Statistics (DES), Ministry of Agriculture since 1970-71 (MOSPI, GOI).

The cost of production of agricultural crops is the most important factor that CACP considers while making its recommendations on MSPs to the Government. In the current study, these data were collected for Tamil Nadu for the three five year periods for paddy and sugarcane from 2000-01 to 2004-05, 2005-06 to 2009-10 and 2010-11 to 2014-15. These results were presented in the table 1 .

\section{Results and Discussion}

\section{Paddy}

The results over the period have shown that amount spent on human labour has increased by Rs 13932/ha in the third period and among the various type of human labour, casual labour occupied a major share of $20.42 \%$ of the total cost. Wage cost depends on the wage-rate and the labour-hours applied in cultivation. Increased mechanization and reduced livestock population resulted in decreased usage of bullock labour over the years and hence the amount spent on bullock labour has reduced by Rs 512/ha. Between three periods usage of machine labour has increased by Rs 6518/ha and constitute 9.12 per cent during I period and 13.59 per cent of the total cost in III period. High yielding varieties demand more input usage and hence increased usage of high yielding varieties over the period contributed to higher cost spent for seed (Rs 3557/ha), fertilizer (Rs 3587/ha), insecticides (Rs 933/ha), and irrigation (Rs. 453/ha). Thus over the period the total operational cost has increased by Rs 30775/ha and it constitutes nearly 70 per cent of total cost in I period and increased to 75.89 per cent in III period. The fixed cost at the end of III period has increased by Rs 7421/ha. As a result of increase in operational and fixed cost, the total cost has increased by Rs 38196/ha whereas the total profit over the same period has risen only by Rs 4419/ha. Thus increase in cost of cultivation was almost 9 times higher than the profit realized by the farmers in the study period.

\section{Sugarcane}

Like paddy, sugarcane is a high input demand crop and hence the operational cost has risen by Rs 71997 over the period. The contribution of operational cost in the total cost has increased by 65.82 per cent in I period to Rs. 77.34 per cent in III period. Increased wage rate of labour resulted in high labour cost which increased by Rs 30000/ha in the III period. The contribution of casual labour cost in total cost has increased by 7.13 per cent to 23.52 per cent. The cost of bullock labour and machine labour has also raised by Rs 325 and Rs 1037/ha respectively. As expected the contribution of bullock labour cost in the total cost has reduced but interestingly the contribution of machine labour has reduced from 1.44 per cent to 1.32 per cent. The cost of cultivation of crops has been increasing over the years because of increases in wage rate of labour, input prices and other managerial costs (Narayanamoorthy 2007). Amount spent for setts, fertilizer, manure and insecticides has also risen from I to III period. Though the percentage contribution of fixed cost in the total cost has reduced from 34.18 per cent to 22.66 per cent but in absolute terms fixed cost has increased by Rs 12077/ha. Increased operational and fixed cost increased the total cost by Rs 84075/ha. 
Table.1 Changes in cost of cultivation of paddy and sugarcane in Tamil Nadu (Rs/ha)

\begin{tabular}{|c|c|c|c|c|c|c|}
\hline & \multicolumn{3}{|c|}{ Paddy } & \multicolumn{3}{|c|}{ Sugarcane } \\
\hline & I & II & III & I & II & III \\
\hline Operational Cost & $\begin{array}{r}20704.19 \\
(69.85) \\
\end{array}$ & $\begin{array}{r}29890.78 \\
(71.00) \\
\end{array}$ & $\begin{array}{r}51479.25 \\
(75.89) \\
\end{array}$ & $\begin{array}{r}39843.07 \\
(65.82) \\
\end{array}$ & $\begin{array}{r}63902.09 \\
(73.19) \\
\end{array}$ & $\begin{array}{r}111840.72 \\
(77.34) \\
\end{array}$ \\
\hline \multicolumn{7}{|l|}{ Human labour } \\
\hline Family & $\begin{array}{r}2677.20 \\
(9.03)\end{array}$ & $\begin{array}{r}4779.76 \\
(11.35)\end{array}$ & $\begin{array}{r}9161.62 \\
(13.51)\end{array}$ & $\begin{array}{r}17668.01 \\
(29.19)\end{array}$ & $\begin{array}{r}32954.09 \\
(37.74)\end{array}$ & $\begin{array}{r}44514.59 \\
(30.78)\end{array}$ \\
\hline Attached & $\begin{array}{r}199.41 \\
(0.67)\end{array}$ & $\begin{array}{r}373.88 \\
(0.89)\end{array}$ & $\begin{array}{r}356.73 \\
(0.53)\end{array}$ & $\begin{array}{r}2377.47 \\
(3.93)\end{array}$ & $\begin{array}{r}1773.21 \\
(2.03)\end{array}$ & $\begin{array}{r}1163.16 \\
(0.80)\end{array}$ \\
\hline Casual & $\begin{array}{r}6632.43 \\
(22.38)\end{array}$ & $\begin{array}{r}8687.48 \\
(20.64)\end{array}$ & $\begin{array}{r}13850.11 \\
(20.42)\end{array}$ & $\begin{array}{r}4318.65 \\
(7.13)\end{array}$ & $\begin{array}{r}8862.26 \\
(10.15)\end{array}$ & $\begin{array}{r}34012.32 \\
(23.52)\end{array}$ \\
\hline Total & $\begin{array}{r}9436.11 \\
(31.84) \\
\end{array}$ & $\begin{array}{r}13841.12 \\
(32.88) \\
\end{array}$ & $\begin{array}{r}23368.46 \\
(34.45) \\
\end{array}$ & $\begin{array}{r}24196.82 \\
(39.97) \\
\end{array}$ & $\begin{array}{r}43589.55 \\
(49.93) \\
\end{array}$ & $\begin{array}{r}79689.87 \\
(55.11) \\
\end{array}$ \\
\hline \multicolumn{7}{|l|}{ Bullock labour } \\
\hline Hired & $\begin{array}{r}362.00 \\
(1.22)\end{array}$ & $\begin{array}{r}252.77 \\
(0.60)\end{array}$ & $\begin{array}{r}181.81 \\
(0.27)\end{array}$ & $\begin{array}{r}107.61 \\
(0.18)\end{array}$ & $\begin{array}{r}255.79 \\
(0.29)\end{array}$ & $\begin{array}{r}555.81 \\
(0.38)\end{array}$ \\
\hline owned & $\begin{array}{r}423.75 \\
(1.43)\end{array}$ & $\begin{array}{r}224.46 \\
(0.53)\end{array}$ & $\begin{array}{l}85.94 \\
(0.13)\end{array}$ & $\begin{array}{r}124.55 \\
(0.21)\end{array}$ & $\begin{array}{l}78.12 \\
(0.09)\end{array}$ & $\begin{array}{l}80.58 \\
(0.06)\end{array}$ \\
\hline Total & $\begin{array}{r}780.20 \\
(2.63)\end{array}$ & $\begin{array}{r}477.23 \\
(1.13)\end{array}$ & $\begin{array}{r}267.75 \\
(0.39)\end{array}$ & $\begin{array}{r}310.42 \\
(0.51)\end{array}$ & $\begin{array}{r}333.91 \\
(0.38)\end{array}$ & $\begin{array}{r}636.39 \\
(0.44)\end{array}$ \\
\hline \multicolumn{7}{|l|}{ Machine labour } \\
\hline Hired & $\begin{array}{r}2438.54 \\
(8.23) \\
\end{array}$ & $\begin{array}{r}5442.94 \\
(12.93) \\
\end{array}$ & $\begin{array}{r}8872.00 \\
(13.08) \\
\end{array}$ & $\begin{array}{r}706.74 \\
(1.17) \\
\end{array}$ & $\begin{array}{r}1254.33 \\
(1.44) \\
\end{array}$ & $\begin{array}{r}1695.58 \\
(1.17) \\
\end{array}$ \\
\hline Owned & $\begin{array}{r}122.69 \\
(0.41)\end{array}$ & $\begin{array}{r}122.10 \\
(0.29)\end{array}$ & $\begin{array}{r}349.13 \\
(0.51)\end{array}$ & $\begin{array}{l}99.02 \\
(0.16)\end{array}$ & $\begin{array}{r}102.59 \\
(0.12)\end{array}$ & $\begin{array}{r}216.42 \\
(0.15)\end{array}$ \\
\hline Total & $\begin{array}{r}2703.10 \\
(9.12)\end{array}$ & $\begin{array}{r}5565.03 \\
(13.22)\end{array}$ & $\begin{array}{r}9221.13 \\
(13.59)\end{array}$ & $\begin{array}{r}874.40 \\
(1.44)\end{array}$ & $\begin{array}{r}1356.92 \\
(1.55)\end{array}$ & $\begin{array}{r}1911.99 \\
(1.32)\end{array}$ \\
\hline \multicolumn{7}{|l|}{ Others } \\
\hline Seed & $\begin{array}{r}2354.74 \\
(7.94)\end{array}$ & $\begin{array}{r}3238.20 \\
(7.69)\end{array}$ & $\begin{array}{r}5912.42 \\
(8.72)\end{array}$ & $\begin{array}{r}3491.93 \\
(5.77)\end{array}$ & $\begin{array}{r}4212.27 \\
(4.82)\end{array}$ & $\begin{array}{r}6780.92 \\
(4.69)\end{array}$ \\
\hline Fertilizer & $\begin{array}{r}2538.17 \\
(8.56)\end{array}$ & $\begin{array}{r}3242.63 \\
(7.70)\end{array}$ & $\begin{array}{r}6125.67 \\
(9.03)\end{array}$ & $\begin{array}{r}5014.21 \\
(8.28)\end{array}$ & $\begin{array}{r}6161.30 \\
(7.06)\end{array}$ & $\begin{array}{r}9649.55 \\
(6.67)\end{array}$ \\
\hline Manure & $\begin{array}{r}759.21 \\
(2.56)\end{array}$ & $\begin{array}{r}922.08 \\
(2.19)\end{array}$ & $\begin{array}{r}2301.65 \\
(3.30)\end{array}$ & $\begin{array}{r}918.65 \\
(1.52)\end{array}$ & $\begin{array}{r}922.93 \\
(1.06)\end{array}$ & $\begin{array}{r}2359.68 \\
(1.63)\end{array}$ \\
\hline Insecticides & $\begin{array}{r}387.90 \\
(1.31)\end{array}$ & $\begin{array}{r}693.99 \\
(1.65)\end{array}$ & $\begin{array}{r}1321.06 \\
(1.95)\end{array}$ & $\begin{array}{r}144.17 \\
(0.24)\end{array}$ & $\begin{array}{r}365.87 \\
(0.42)\end{array}$ & $\begin{array}{r}480.68 \\
(0.33)\end{array}$ \\
\hline Irrigation Charges & $\begin{array}{r}1192.42 \\
(4.02)\end{array}$ & $\begin{array}{r}1136.04 \\
(2.70)\end{array}$ & $\begin{array}{r}1646.30 \\
(2.43)\end{array}$ & $\begin{array}{r}2804.50 \\
(4.63)\end{array}$ & $\begin{array}{r}3713.84 \\
(4.25)\end{array}$ & $\begin{array}{r}4755.04 \\
(3.29) \\
\end{array}$ \\
\hline Miscellaneous & $\begin{array}{r}6.61 \\
(0.02) \\
\end{array}$ & $\begin{array}{c}12.38 \\
(0.03) \\
\end{array}$ & $\begin{array}{c}32.46 \\
(0.05)\end{array}$ & $\begin{array}{r}0.05 \\
(0.00) \\
\end{array}$ & $\begin{array}{r}7.86 \\
(0.01) \\
\end{array}$ & $\begin{array}{r}0.00 \\
(0.00) \\
\end{array}$ \\
\hline $\begin{array}{l}\text { Interest on Working } \\
\text { Capital }\end{array}$ & $\begin{array}{r}545.73 \\
(1.84)\end{array}$ & $\begin{array}{r}760.94 \\
(1.81)\end{array}$ & $\begin{array}{r}1282.36 \\
(1.89)\end{array}$ & $\begin{array}{r}2087.92 \\
(3.45)\end{array}$ & $\begin{array}{r}3237.64 \\
(3.71)\end{array}$ & $\begin{array}{r}5576.20 \\
(3.86)\end{array}$ \\
\hline Fixed Costs & $\begin{array}{r}8936.21 \\
(30.15)\end{array}$ & $\begin{array}{r}12208.20 \\
(29.00)\end{array}$ & $\begin{array}{r}16357.52 \\
(24.11)\end{array}$ & $\begin{array}{r}20690.13 \\
(34.18)\end{array}$ & $\begin{array}{r}23407.14 \\
(26.81)\end{array}$ & $\begin{array}{r}32767.80 \\
(22.66)\end{array}$ \\
\hline $\begin{array}{l}\text { Rental Value of } \\
\text { Owned Land }\end{array}$ & $\begin{array}{r}6279.60 \\
(21.19)\end{array}$ & $\begin{array}{r}8606.09 \\
(20.44)\end{array}$ & $\begin{array}{r}11282.38 \\
(16.63)\end{array}$ & $\begin{array}{r}14494.33 \\
(23.94)\end{array}$ & $\begin{array}{r}17105.92 \\
(19.59)\end{array}$ & $\begin{array}{r}24772.65 \\
(17.13)\end{array}$ \\
\hline Rent Paid for & 301.16 & 459.28 & 358.80 & 343.25 & 42.68 & 165.51 \\
\hline
\end{tabular}




\begin{tabular}{|l|r|r|r|r|r|r|} 
Leased-in-land & $(1.02)$ & $(1.09)$ & $(0.53)$ & $(0.57)$ & $(0.05)$ & $(0.11)$ \\
\hline Land Revenue & 87.27 & 91.13 & 7.12 & 94.03 & 159.69 & 10.73 \\
Cesses and Taxes & $(0.29)$ & $(0.22)$ & $(0.01)$ & $(0.16)$ & $(0.18)$ & $(0.01)$ \\
\hline Depreciation on & & & & & & \\
Implements and & 412.19 & 407.03 & 371.94 & 574.25 & 573.12 & 660.29 \\
Farm Building. & $(1.39)$ & $(0.97)$ & $(0.55)$ & $(0.95)$ & $(0.66)$ & $(0.46)$ \\
\hline Interest on Fixed & 1855.98 & 2644.67 & 4337.28 & 5184.28 & 5525.76 & 7158.42 \\
Capital & $(6.26)$ & $(6.28)$ & $(6.39)$ & $(8.56)$ & $(6.33)$ & $(4.95)$ \\
\hline & $\mathbf{2 9 6 4 0 . 4 0}$ & $\mathbf{4 2 0 9 8 . 9 9}$ & $\mathbf{6 7 8 3 6 . 7 7}$ & $\mathbf{6 0 5 3 3 . 1 9}$ & $\mathbf{8 7 3 0 9 . 2 5}$ & $\mathbf{1 4 4 6 0 8 . 5 2}$ \\
Total Cost (C2) & $\mathbf{( 1 0 0 )}$ & $\mathbf{( 1 0 0 )}$ & $\mathbf{( 1 0 0 )}$ & $\mathbf{( 1 0 0 )}$ & $\mathbf{( 1 0 0 )}$ & $\mathbf{( 1 0 0 )}$ \\
\hline Value of Main & & & & & & \\
Production/ha.(Rs) & 27205.04 & 42731.50 & 68360.36 & 77067.17 & 125981.83 & 218098.10 \\
\hline Value of By- & & & & & & \\
Production/ha.(Rs) & 3369.15 & 3137.97 & 4829.87 & 1400.81 & 2431.52 & 3287.83 \\
\hline Total output Value & 30574.19 & 45869.47 & 73190.24 & 78467.97 & 128413.34 & 221385.93 \\
\hline Total profit & 933.79 & 3770.49 & 5353.47 & 17934.78 & 41104.09 & 76777.41 \\
\hline
\end{tabular}

Note: Figures in the parenthesis indicate percentage to total

The output value over the years has increased and hence profit has increased by Rs 58842/ha. But rise in total cost of cultivation was much higher than the profit achieved by the farmers.

From the results of the study it is evident that over the years, increase in cost of cultivation of paddy and sugarcane was disproportionate with rise in profit. Also it is observed that, over the years there has been a change in the share of operational and fixed cost in the total cost. In case of both paddy and sugarcane, fixed cost has been reduced from 30.15 per cent to 24.11 per cent and 34.18 per cent to 22.66 per cent respectively, mainly because of increase in the share of operational cost to the total cost. Among the cost components, labour and fertilizer occupies a huge share in cost of cultivation. Fertilizer cost account for the second largest component, after wages, in the operational costs of cultivation. Since it is an important input contributing to higher productivity, there is an inclination among farmers to go on increasing the application of chemical fertilisers without understanding the after effect problems. Application of more chemical fertilisers induces the growth of weeds and pests. This in turn requires more application of herbicides and pesticides. Hence proper understanding about scheduled application of fertilisers is essential. Also usage of short duration varieties, demand more intercultural operations in a shorter period. This will be possible only farmers can mechanise different operations starting from land preparation to threshing. Hence in order to reduce the cost of cultivation, the study called for efficient use of resources.

\section{References}

http://mospi.nic.in/412-cost-cultivationprincipal-crops

Narayanamoorthy, A (2007): 'Deceleration in Agri cultural Growth: Technology Fatigue or Policy Fatigue?' Economic \& Political Weekly, June 23, pp. 2375-79.

\section{How to cite this article:}

Kavitha, V. and Chinnadurai, M. 2017. Changing Pattern of Input Cost in Tamil Nadu, India. Int.J.Curr.Microbiol.App.Sci. 6(12): 430-433. doi: https://doi.org/10.20546/ijcmas.2017.612.052 